\title{
Remarks on the Reasoning: The Morals of a Hungarian Expulsion Decision in Times of Pandemic ${ }^{1}$
}

\author{
Erzsébet Csatlós \\ University of Szeged, Faculty of Law and Political Sciences, Institute of Public \\ Law, Hungary \\ csatlos.e@juris.u-szeged.hu \\ https://orcid.org/0000-0001-8129-6189
}

Received: 21. 1.2021

Accepted: 28. 4. 2021

\section{ABSTRACT}

Several Iranian university students were expelled from Hungary to Iran due to their (allegedly) unlawful behaviour during their quarantine period at the outburst of the Covid-19 pandemic on grounds of being a threat to public policy and public security. The case reveals a worrisome practice in the reasoning of expulsion decisions, irrespective of the pandemic. By analysing a judgment on the review of an administrative decision on expulsion, the article explores the normative circumstances of the legal institutions appearing in the case. By comparing international, European Union, and Hungarian constitutional practice, the study reveals a controversial legal practice. It not only evaluates the case, but draws attention to the role, quality, and legal significance of reasoning of administrative acts which lately, with a quickly changing legislation, seems to be forgotten.

Keywords: expulsion, reasoning of decisions, fair procedure, effective legal remedy, procedural guarantees

$J E L: K 3, K 4, K 42$

1 This research was supported by the project nг. EFOP-3.6.2-16-2017-00007, titled Aspects on the development of intelligent, sustainable and inclusive society: social, technological, innovation networks in employment and digital economy. The project has been supported by the European Union, co-financed by the European Social Fund and the budget of Hungary. The article is a revised version of the presentation entitled 'The Bermuda Triangle of Expulsion, Reasoning of Decision and Effective Legal Remedy in the Hungarian Legal Practice' presented online at the 13th International Biennial Conference of the Faculty of Law of the West University of Timișoara. 


\section{Introduction: A controversial case at the dawn of the pandemic}

In Spring of 2020, soon after the state of emergency was announced ${ }^{2}$ in Hungary, there was a case that received huge press coverage. ${ }^{3}$ Several Iranian university students were expelled from Hungary to Iran based on their unlawful behaviour during their quarantine period. The case that gives occasion for discussion is about an Iranian university student among them who had legally resided in Hungary for the past 9 years. She was quarantined with a group of other Iranian students and released from the quarantine on 12 March 2020 as she showed no signs of infection. Meanwhile, as she was accused of committing the crime of violation of epidemic controlling measures by leaving her hospital ward without permission once during the quarantine and behaved aggressively. She denied the accusation (Judgment, para. 3) but on 13 March 2020, the immigration authority expelled her from the territory of the European Union by deportation and ordered the expulsion and the ban on re-entry for 3 years. (Judgment, para. 3); Constitutional complaint, para 4.). ${ }^{4}$ Later, during the criminal proceedings, the accusation was modified as the previous one contained a date of violation of rules when she had not been in the hospital yet, so obviously had not been able to commit any crimes. The date was then modified, and the later document mentioned no aggressivity. Finally, the expulsion was carried out on 16 April 2020 with an official escort to the state border of Hungary. A constitutional complaint was also submitted to the Constitutional Court with the request to annul the Metropolitan Court's judgment (along with others on the same reason of expulsion). ${ }^{5}$

The authority decision was based on the proposal of the investigating authority (police) in the criminal case, stating that her presence is a threat to public security and public order due to a well-founded suspicion of the violation of ep-

2 In Spring, the state of emergency from 11 March was declared by Government Decree 40/2020. (III. 11.) and was put an end to it on 18 June 2020 by Government Decree 282/2020. (VI. 17.).

3 For example, see the official government website for Covid-19 news: Coronavirus: Another 13 Iranian Students Expelled for Violating Quarantine Rules. MTI-Hungary Today 2020.03.16. at <https://hungarytoday.hu/coronavirus-iranian-students-hungary-expelled/> accessed 10 January 2021.

4 According to the judgment, the expulsion was ordered on the basis of Article 43 (2) point d) of the Act on TCN which states as follows: the immigration authority shall order the expulsion of a third-country national under immigration laws (...) d) whose entry and residence represents a threat to national security, public security or public policy; (...). and Article 43 (3) that "[a]n independent exclusion order, and an expulsion order under immigration laws may be issued upon the initiative of law enforcement agencies delegated under the relevant government decree on the grounds referred to, respectively, in (...) Paragraph d) of Subsection (2) within the framework of discharging their duties relating to the protection public policies defined by law. Where (...) expulsion is ordered under Paragraph d) of Subsection (2), the law enforcement agencies delegated under the relevant government decree shall make a recommendation as to the duration of such exclusion in cases falling within their jurisdiction. The competent immigration authority shall not derogate from said recommendation." The ordering of expulsion with an official escort was based on Article 65 (1) point c) of the same Act, while the ban on re-entry was based on Article 47(4) and Article 119 of the Executive Decree. The English text is available in the National Legal Database only for subscribers.

514 other complaints were submitted between 3 June and 18 September 2020 to the Constitutional Court in the issue of expulsion on the grounds of violation of epidemic controlling measures. See, Alkotmánybíróság, current agenda at < http://hunconcourt.hu/current-agenda accessed> 30 December 2020. 
idemic measures. She applied for the only available legal remedy in the case: a court review. Having a look at the final and binding judgment [Judgment] of the Metropolitan Court, it reveals a worrisome practice on the reasoning of expulsion decisions that seems to be irrespective of the pandemic.

\section{Grounding of administrative decisions: Research questions and the way to find answers}

The anonymised court judgment was handled by the Hungarian Helsinki Committee who represented one of the Iranian students in question as, despite the legislation that orders the courts to upload the anonymised judgments to a public database, it is still not available in the system. ${ }^{6}$

The Metropolitan Court did not contest the authority decision thus declared the action for judicial review unfounded (Judgment, para. 7). It responded to some parts of the claim, ${ }^{7}$ like the argumentation on the non-application of the principle of non-refoulment as the legal remedy claim referred to the lack of the country information and evidence on what basis the asylum authority had issued its opinion to the immigration authority. (Judgment, para. 5). However, it completely refused to re-examine the basis of the whole procedure as identified no procedural error since the authority decision mentioned the police initiation as legal background and due to the obligatory nature of the police initiation, the immigration authority fulfilled its obligation of reasoning by purely referring to this fact. The factual basis and their evaluation of the police proposal were incorporated in neither the authority decision nor the judgment; it was only presented to the Student during her hearing (Judgment, para 20.) on the same day the expulsion decision was issued. Recalling the de facto special authority nature of the police, the legal remedy claim called attention to the missing procedural guarantees belonging to this legal institution, namely, the incorporation of the factual and legal grounding of the police proposal findings as a crucial element of the immigration authority decision (Judgment, рага. 5.).

In the legal remedy phase, the Metropolitan Court denied the police being a special authority (Judgment, para. 17) and declared that the relevant procedural law was respected by the immigration authority, and its decision is conformity to the law (Judgment, para. 9) meanwhile, the reason why the Student posed a threat to public security and public order remained unknown. Besides, there were confusing changes in the police documentation on the alleged breach of law: the time of commitment was changed, and the accusation of aggressive behaviour also disappeared in a later protocol (Constitutional com-

6 The Author is grateful to Dr. Eszter Kirs legal officer for providing the anonymized version of the Metropolitan Court's judgment. Anonymised court decisions, with some exceptions, are to be published within 30 days counting from its putting in writing with free availability in an online system (at <https://eakta.birosag.hu/anonimizalt-hatarozatok> accessed 10 January 2021) according to Art. 163 of Act CLXI of 2011 on the organization and administration of courts. At the time of writing of this paper, the Judgment was not available in the database.

7 The legal basis of the expulsion (Judgment, para. 5.); the applicability of the non-refoulment principle (Judgment, para. 22-24.), the right to private life (Judgment, para. 24.) the right to be heard during the procedure (Judgment, para. 25.). 
plaint, рага. 3). All legal problems are linked by one core element: the lack of factual reasoning of decisions in the case. Both the administrative authority decision and the Court judgment referred to the facts and reasoning of a police initiation as obvious and responsive reasons of the measure taken, but none of them incorporated anything but that provision of the Act on the Admission and Right of Residence of Third-Country Nationals (Act on TCN), that makes the police initiation binding upon the immigration authority. Besides, the concrete legal basis of the decision that names the threat to public security, public policy or public order, namely point d) of Article 43 (2) of the Act on TCN was missing. No facts, no reasons, no explanation just the pure reference to the police initiation and its binding nature by invoking the legal norm to support that.

The question is therefore if it is sufficient and adequate legal basis to refer to the obligatory nature of reasoning of a proposed measure coming from another authority to ground a decision. Furthermore, does this type of reasoning substitutes the factual and legal explanation part in an administrative authority decision in the view of rule of law requirements for administrative proceedings? May it be called fair procedure when even after judicial review, the subject gets no answer on the reasons for the measure taken? The sense of law gives a hint of the prejudice of negative but to make sure, the Hungarian normative circumstances are explored step by step.

Decisions of administrative authorities are not available for the public, so the historical facts of the case are based on the state of affairs incorporated in the Judgment (рага. 1-3) and the state of affairs summarised in the Constitutional complaint (рага. 1-4) and the legal statements of the Judgment are evaluated in the view of the international standards, the constitutional practice and the administrative procedural provisions related to the reasoning of administrative decisions. All support the hint even in the state of emergency, and also by exploring the domestic normative background, a worrisome legislative development is revealed.

\section{Findings on the legal reasoning of administrative decisions and the evaluation of the Hungarian practice}

\subsection{The grounding of the decision on expulsion in the primarily applicable law in force}

The Act on TCN enlists the basic content of the immigration authority decision and also enlists the extra elements related to the circumstances of the expulsion. (Act on TCN, art. 46 (1)-(1a)) The basic is, however, the same as all the classical elements of a formal authority decision with expressed reference to reasoning. Reasoning shall contain the statement of facts and the reasons for the opinion of the special authority involved in the procedure. (Act of TCN, art. 87/M (1) cf. GPAP, art. 81 (1) and Boros, 2006, p. 420). Also, a law or government decree (d) may lay down additional detailed rules for certain types of cases (Act on TCN, art. 87/M (2)). 
Since the entry into force of the new procedural code in 2018, immigration cases due to their specific procedural features are under the scope of only specific procedural acts as in this case, it is the Act on TCN, (GPAPC, art. 8 (1) d)) while it does not mean that referring to general rules has no place and the predeceasing legal practice, that was relevant for immigration authority proceedings before, disappeared without any trace (Patyi, 2012, p. 79). The constitutional based procedural right guarantees and their achievements developed in practice penetrates all authority procedures (GPAPC, art 1. referring to FL, art. XXIV. and XXVIII; GPAPC Commentary to art. 1. para 1.; art 3, para. 2). These provisions are dominating over the application of specific procedural rules as serving higher values of legality, therefore the relevant guideline findings developed by case law, regardless of whether the authority procedure is falling inside or outside of the scope of the general public administration procedures code, are unavoidable (Balogh-Békési, 2016, p. 14). Those procedures that do not fall under the scope of the general code due to their distinctive features are still authority procedures, therefore the constitutional requirements apply to them (Hajas, 2016, p. 19; Varga, 2019, pp. 163-169). The practice developed continues to exist in the absence of a specific regulation, based on more abstract concepts, as the goal is still the same: to make a lawful decision suitable for judicial review (Váradi-Tornyos, 2018, p. 185). The controllability of legality and to avoid arbitrariness still requires authorities to justify their decisions appropriately (Patyi-Varga, 2019, p. 41).

The Metropolitan Court defines its path to follow when it recalls the constitutional provision that orders to examine the lawfulness of the authority act by interpreting the relevant legal provisions in the view of the Fundamental Law, the constitution of Hungary (Judgment, para 11.; FL, art. 28.).

Factual and legal reasoning is generally a procedural guarantee and key to legality of both administrative and judicial decision acknowledged as such by the Council of Europe, (Hirvisaari v. Finland, para. 30; Suominen v. Finland, рага. 37; Baucher v. France, para. $47-51)^{8}$, the Court of Justice of the European Union (EU Charter, Article 41 (2) c); TFEU, art. 296.) ${ }^{9}$ and by the Hungarian constitutional practice.

Article XXIV (1) of the Fundamental Law now clearly expresses the right to fair administrative procedure and the obligation of authorities to ground their decisions but it also has a long-standing practice (Chronowski, 2014, p. 143). The Hungarian Constitutional Court supported its statements by the Strasbourg case-law (7/2013 CCD pp. 387-388 [31]) when it called attention that the importance of thoroughness of the essential parts of the case as a mini-

8 However, Article 6 (1) of the Convention for the Protection of Human Rights and Fundamental Freedoms and the case-law refers to judicial decisions, there is no evidence that administrative procedures fall under lighter requirements for procedural. Indeed, the obligation of reasoning of decisions is one of the main administrative procedural principles. (Stelkens and Andrijauskaite, 2017, p. 24.; Hepburn, 2012, p. 15.; CoE Handbook, 2018; pp. 35-36). The right to fair procedure echoed in Article 6 . is in fact determines the possible extent of judicial review. (Dudás and Kovács, 2018, pp. 158-159).

9 In exceptional cases, especially in the case of encrypted documents, the incomplete statement of reasons may be legally recognized, but even in such a situation, the argumentation shall never be deprived of its meaning (Martin, 2019, p. 2207; Opdebeek and Somer, 2016, p. 115). 
mum requirement for reviewability of authority decisions. Besides, the court also must give an analytical explanation in a manner that conforms with all the circumstances of the case (7/2013 CCD, p. 387-388. para. 31; 34). This requirement is not met when the superior court upholds the lower court's arguments on the substance of the case without further examination and without stating the reasons for the investigation, (7/2013 CCD pp. 387-388. рага. 31). and that has just happened in the Iranian Student's case. Although the legal practice was clear: based on the constitutional basics, following the relevant procedural laws in a concrete case, a decision shall be justified by facts, proofs and by the explication of their evaluation and the motifs behind deliberation. If the obligation for reasoning is not in conformity with these constitutional standards, it means that the procedural law is interpreted and applied unconstitutionally (7/2013 CCD p. 388. para. 34). It was also acknowledged that the reasoning of administrative decisions is the proof of its legality as well it establishes the possibility of verifying if the administration functions within the frames of law. Therefore, the obligation of reasoning is one of the guarantees of a lawful and fair process (5/2019 CCD, p. 415. Рага. 13; T-425/04, рага. 315; T-256/11 рага. 107.; T-107/15, рага. 111; C417/11 P рага. 50 and 53.; C-566/14 P, para. 69). Thus, it is key to an effective legal remedy.

As for the State of emergency, the application of constitutional rights may be restricted (FL, Art. 54 (1)) but even in such case, the restriction shall be done if it necessary and proportionate to the objective pursued and it may not deprive the relevant fundamental law of its essential content. (FL, art. I (3) see also ICCPR comment, para 16.). As for the derogation, none of the Government decrees suspended (or limited) the duty of authorities to ensure fair procedure, grounding of decisions and effective legal remedy.

\subsection{The Hungarian legal practice on the insufficient legal and factual grounding of administrative decisions}

The Constitutional Court interpreted the obligation of reasoning as a part of fair procedure requirements and judicial practice made it clear that the ignoration or violation of the duty of grounding as a procedural guarantee result in an infringement of the law affecting the merits of the case even if the authority would otherwise make the same administrative decision in compliance with the guarantee rules (EBH2017. K.8.) As for the content and quality of this obligation, the authority shall state the facts including the matching of factual elements with the applicable legislation and the detailed explanation of the legal statements (BH2019.91.) It follows that referring to merely a legal act, as here, in this case, the provision that makes the police initiation obligatory and explaining and interpreting this obligatory nature form different angles (Judgment, para. 16-18), is not in conformity with the requirements established by law and settled by constitutional and judicial practice.

Legal reasoning shall also include the proper reference to the legal provision that serves as the basis of the decision. The complete failure to indicate legislation is a serious insufficiency, and the legal reference cannot be replaced 
by the court while doing a review (BH2016.316.) For this reason, the finding of the Metropolitan Court that argues that the legal basis on which the decision is based (namely, point d) of Art. 43 (2) of the Act on TCN) can be "clearly established" (Judgment, para. 16) and does not classify its lack as a deficiency, raises concerns. If the breach of the procedure is of such a degree that it renders the authority decision inadmissible on the merits (and the problems of quality of factual and legal reasoning undoubtedly constitute such), the court must name that circumstance. The decision ordering the expulsion of the immigration authority cannot be changed by the court according to the law in force (Act on TCN, art. 88/R (2)), but it may guide the conduct of the new procedure (repeated procedure) ordered in the judgment, covering all relevant points of the remedy of the established violation (CAL, art. 86 (4)). The practice classifies an infringement as unsuitable for a substantive review if the statement of reasons does not establish the legality of the decision; (KGD2013.47.) the decision, concerning the available data, facts, legal basis, and legal consequence, is not clear about the reasons and motifs of deliberation; (KGD2015.91.) or the decision has no facts, legal reasons and does not contain the legal bases on which the decision is based. (KGD2012.196.).

It seems that either both the Court and the authority made a procedural mistake, or the police proposal is untouchable and falls outside all requirements related to procedural guarantees.

\subsection{The obligation of reasoning if other authority contributions are involved in the decision-making process}

3.3.1 The procedural role of the police proposal for the expulsion and ban on re-entry

The Metropolitan Court argued that the ongoing criminal proceedings that served the basis of the investigating authority's proposal for the expulsion are completely separated from the immigration authority's procedure that ordered the requested measure, and there is no relationship between the outcome of the criminal procedure and the administrative legal consequence of the (alleged) behaviour that happens to be the object of the criminal case. Therefore, there is no reason to contest this part, including the content of the proposal with its factuality and legality and there is no possibility to invoke the criminal law related (Constitution 57. § (2); Kfv.III.27.519/1997/6.; Kf.II.25074/1994/4. cf. FL, art. XXVIII (2) GPAPC Commentary, art. 1. para. 10) right to presumption of innocence to revoke the administrative decision of expulsion. (Judgment, рага. 20).

Legal practice is consistent in requiring the demarcation in reviewing procedures: the activity of the police, as an investigating authority, and its procedural activities concerning investigations is not a subject of administrative litigation, (BH2011.179.) the administrative court has no constitutional empowerment to review activities related to criminal procedures. (KFv.III.37.315/2012/4.; GPAPC Commentary, art 7. para. 8). Among other things, this may explain the 
fact that the content of the proposal of the investigating authority - the facts establishing the threat to public order and its classification - could not be examined by the Metropolitan Court. However, this explanation cannot save the lack of obligatory elements in the immigration authority decision, except for the case if it would have been classified information. ${ }^{10}$ Nevertheless, in the Iranian Student's case, this reason did not even occur. Meanwhile, it shall be noted, that even in case of classification, the possibility to have access to the classified document by claim and also a legal remedy in case of denial is ensured by law. (Act CLV of 2009, art. 11.) International practice acknowledges if the documentation in a case is not a part of the reasoning but available in a separate document (C-16/65, p. 888; C-119/97 para. 57).

However, the right to submit a proposal which is order and not a suggestion to consider raises further questions especially in the view of the legal remedy claim addressed to the court, namely the reference to the police as a special authority.

This latter in the Hungarian administrative authority practice is a manifestation of a sort of task -sharing: the proceeding authority issues the decision within the competence and the special authority, upon the assignment by act or government decree, assess a clearly and precisely defined special issue related to the case. The involvement of the special authority and the respect of its professional opinion is obligatory, it leaves no room for deliberation, and the proceeding authority is also obliged to incorporate the factual and legal considerations of the assessment into its grounding of the decisions of the proceeding authority; otherwise, the violation of either of these rules causes nullity of the decision (GPAPC, art. 55 (1); 123 b)). The legal remedy is thus ensured against the assessment by a claim against the proceeding authority's decision (GPAPC, art. 55 (4) Huszárné Oláh, 2017, p. 137.; Kálmán, 2018, p. 113). In immigration cases, the law provides for the involvement of special authorities (Act on TCN, art. 78 (4); Executive Decree, art. 72/H; 97; 97/A; 106/A; 165) cf. Immigration Law Practice, 2013, p. 26), but despite the obvious resemblance to the role of the contribution of the police or the asylum authority, none of them is considered as such. The investigating authority is not an actor in the procedure, but its contribution led to the opening of the immigration authority procedure. This type of relationship with the proceeding authority does not qualify special authority involvement not in the case if it leads to an obligatory starting of the procedure. (2.KF. 28.405/2004/2.; GPAPC Commentary, art. 55. para. 7). It cannot be categorised as a related procedure either as it would assume a decision on the side of the police, however, there is no such thing, but a proposal based on some presumption (GPAPC, art. 45 and its legislative motifs).

\subsubsection{The asylum authority's opinion on the non-refoulment principle}

The immigration authority is under obligation to request the opinion of the asylum authority to determine as to whether the principle of non-refoulment

10 KGD2016. 27. In this case, the proposal was made by the Counter-Terrorism Centre. See similar, refusal of constitutional complaint in the case of decision $42 . K .32 .031 / 2019 / 8$. by 3171/2020. CCO, р. 899, рага. 14-15. 
applies if the issue of expulsion occurs and the asylum authority is obliged to comply with the request without delay. The immigration authority shall not derogate from the opinion on the evaluation of the third country (Executive Decree, art. 124 (3)). So, at first glance, its role is that of special authority, however, the legal practice is clear: In the absence of a designation, a document sent to the authority shall not be considered as a special authority assessment (Immigration law practice, p. 26; Kfv.III.37.587/2011/7.; GPAP Commentary, art. 55. рага. 2). The designation is undoubtedly missing.

It cannot be treated as a seconded expert, according to the general rules, provides means of proof when the proceeding authority lacks the expertise in a significant issue that would be crucial for the outcome of the case. It is incorporated in the proceeding authority's decision among the other means of proof and its evaluation is explained as a part of the grounding, therefore it can be contested by legal remedy against the decision itself (GPAPC, art. 62.; 71 (1); 81(1))). Law may prescribe that a certain proof shall be requested for a case (s the opinion of the asylum authority) but in this case, the asylum authority gives an obligatory assessment that leaves no room for any sort of deliberation. However, even if the Student's legal remedy claim missed the information that supported the qualification of considering Iran as a safe country to return (Judgment, para. 5), the Court gave a detailed explanation on the non-applicability of the non-refoulment principle on the grounds of the higher number of infections there. So, in this issue, the lack of grounding was effectively remedied (although in a negative way for the Student), even if it missed to mark the lack of incorporation of the grounding of the asylum authority's assessment in the decision that ordered the expulsion (Judgment, рага. 22-23).

\subsection{Confusing normative development - missing procedural guarantees?}

In the present case, two authorities appear apart from the proceeding one, each takes a different role and de iure none of them is neither a seconded expert in a specific issue nor a special authority. On the other hand, both produce a significant and unavoidable influence on the decision itself, the expulsion and the normative development of their status is confusing. It clearly shows their growing importance and significance as obligatory assessment providers as both represent sui generis legal institutions. In this case, it means that in the view of the existing procedural institutions; they are unknown per se.

The problem of interpretation of procedural guarantees and classification of a legal phenomenon may be traced back to the legal modifications of immigration law in recent years.

As for the asylum authority, its role was interpreted differently before 2015 and caused controversial practice: upon its opinion on the third country, the immigration authority had the right to individualise the statements in the view of all other data and information of the case of a concrete person. Therefore, the immigration authority had to give reasoning on why it applied or refused 
the country evaluation given by the asylum authority in every case differently (FT 20.K.32.700/2011/10.; 20.K.33.146/2011/4.; Immigration law practice, p. 26.; pp. 112-113). In 2015, the legislation changed: the obligatory nature of the asylum authority was introduced to the provision, depriving the proceeding authority of its discretion and right to deliberate the personal circumstances. ${ }^{11}$

It is an interesting aspect to add, that before 2007, the Hungarian administrative practice knew this type of involvement of obligatory professional opinion in the procedure but without the procedural guarantees in sectoral law. To put an end to such ex lex situation with the lack of proper procedural guarantee, the procedural code in force at that time (which also ruled immigration cases then) was modified ${ }^{12}$ requiring a proper assignment as a special authority (GPAPC commentary, art. 55. point 7). If the legislator aimed to regulate the obligatory nature of the opinion but without ensuring the procedural guarantees related to special authority assessments, at least by analogy, then it is a step back towards an unlawful practice.

Considering the procedural role of the police, the legislator has introduced the possibility to propose to the immigration authority 2010 but before 1 January $2018,{ }^{13}$ the proposal of the investigating authority was indeed a recommendation and not a binding order. Currently, the Act on TCN expressly states that the competent immigration authority shall not derogate from the proposal (Act on TCN, art. 43 (3); KGD2019.105) it is not entitled to override it, neither the necessity of expulsion nor the recommended time of the ban on re-entry (Act on TCN Article 43 (3); legislative motifs to Act CXLIII of 2017, art. Article 38).

The immigration authority proceeds ex officio, whereas another authority gave the hint to open the procedure, (GPAPC Commentary, art. 104. para. 1) however, the analogy does not help this time: there is no similar legal institution in the Hungarian legal practice as all fail at the 'obligatory order' nature of the initiation (cF. Act CLXV of 2013, art. 2/A -3 (1); GRAPS Commentary, art. 29. § (1)-(2) рага. 4. b) and d), cf. GRAPS Commentary, art. 15. para. 4. b); Lapsánszky, 2019. pp. 419-420).

Thereby, there is another example of sui generis legal phenomenon: the proposal maker authority does the fact-finding, the evaluation of the facts and the deliberation and thus de facto the decision- making, while the competent proceeding authority ensures the de iure format of decision-making. In the present case, the full documentation (the detailed matter of facts, and the

11 Introduced by Article 7 of Government Decree 204/2015. (VII. 23.) on the modification of Government Decree 375/2010. (XII. 31.) on aid for public employment and on the legal harmonization of certain migration, asylum, and other government decrees. According to its Article 34, it entered into force on 1 August 2015.

12 According to Article 2 (1) i) of Act CIX of 2006 on amendments to the law related to the formation of governmental organization, Article 58 (6) of GRAPS added the following lines in italics: Act or government decree may stipulate that the proceeding authority is bound by the opinion of a specific scientific or professional body or expert body on a specific issue. In such a case, the rules on the assistance and procedure of the special authority shall apply mutatis mutandis, provided that the same body or body of experts may not act unchanged in the appeal procedure.

13 It was Article 38 of the Act CXLIII of 2017 that inserted the provision into the Act on TCN. 
reasoning of the argumentation that led to the final consequences of expulsion) of this kind of cooperation does not appear in the proceeding authority's decision, thus it raises the question of the legal relationship of authorities that makes this practice possible. Otherwise, the authority decision is, due to its serious insufficiency, unsuitable for a substantive review.

\subsection{Is there a solution in Hungarian legal practice to overcome procedural loopholes?}

After several legal steps of the representant of the Student, the Budapest Police Headquarters declared that the Iranian student was no longer a threat to public policy or public security, therefore, in respect of this statement, the immigration authority withdrew the ban on re-entry by its decision of 9 October $2020 .{ }^{14}$ On this basis, the Constitutional Court declared the complaint expired and closed the case of constitutional complaint (3487/2020 CCO, p. 2739 , рага. 14). Were the authority and the Court right when both kept aloof from the factuality of the police proposal?

In lack of concrete legal provisions, the legal principles may serve as a fulcrum, notably, in this case, the officiality and the clarity of administration. The authority is obliged to enforce the principle of officiality from the beginning of the procedure, through the conduct of the procedure, until its completion and the execution of the decision. This includes the obligation to establish the facts, (30/2015 CCD, p. 787 and p. 792, para. 39 and 53) and, in close connection with that, the appropriate statement of reasons in the light of the principle of fair process (FL, art. XXIV; KFv.I.35.066/2016/7). The Constitutional Court pointed out that the right to a fair procedure (and thus good administration) and ultimately the rule of law is contrary to such authority activity, which interprets the purpose of the legislator to ensure effectivity but at the cost that makes the client vulnerable, and in fact, essentially defenceless against the action of the public authority (165/2011 CCD, P. 1302, рага. V.1.1.). Simplicity (the principle of intelligibility) also serves the interests of the client in this respect, as the conduct of the procedure and the decision itself shall be understandable and clear (GPAPC Commentary, art. 2. para. 5).

The rules on formal decisions are intended to ensure that the client has a complete picture of the facts which the authority has revealed, which had been considered and been refrained in formulating the opinion and under which legal provisions the decision has been made. This point of view has been consistently guiding legal practice for decades (Kfv.I. 35.534/1999.; 4.KF.27.031/2005/9.; 4.Kf.27.369/2006/7, GPAPC Commentary, art. 80. рага. 5), maturing this way, the requirement that the operative part of the decision and the statement of reasons must be consistent with a general principle of law ((Kfv.V.35.538/2009/5.; Kfv.III.35.425/2015/7.; GPAPC Commentary, art. 80. рага. 5).

14 The letter is available as attached to the case files of the Constitutional complaint at <http:// public.mkab.hu/dev/dontesek.nsf/0/DA7553273FBDB2AFC1258589005BEB59?OpenDocum ent> accessed 30 December 2020. 
The decision is well-founded and lawful only if the factual and legal reasons set out in the statement of reasons duly substantiate the authority decision (KF.IV.37.291/2004/2.; GPAPC Commentary, art. 80. para. 5). The justification shall be comprehensive, cover all parts of the decision-making process, and the authority's reasoning logic should be traceable (Kfv.ll..37.191/2006/7). Thus, the adequacy of the content of the decision is a guarantee that the decision can be verified later, and its correctness and legality can be judged on this basis (2.KF.27.236/2008/6.; 2.KF.27.237/2008/7.; GPAPC Commentary, art. 1. para. 6).

Procedural guarantees in immigration proceedings even during a state of emergency as the non-refoulment rule raises human rights and fundamental rights issues that also affect international and EU law obligations of the State (15 of 1989 Decree-Law, art. 33.; FL, art. XIV (4); EU Charter, art. 18-19, cf. Molnár, 2019, pp. 184-202; Tóth, 2015, pp. 63-65; Blutman, 1997, pp. 5-27). If the procedural rules leave loopholes, the interpretation in the view of constitutional values requires the applicability of the guarantees that are connected to a special authority involvement can be derived from the spirit of the law and by legal interpretation, guidelines are given by the Fundamental Law. Therefore, the relevant provisions of the Act on TCN shall be interpreted in a way, that ensures the procedural guarantees around the involvement of the asylum authority the same way as law ensures procedural guarantees in case of the obligatory assessment of the special authorities (Kfv.X.37.055/2001/5.; Kfv.X.37.055/2001/5.; GPAPC Commentary, art. 55. para. 7. and FL, art. XXVII. (7)).

All in all, in the lack of exact legal provision or the possibility to use an analogy, the requirement of the principle of officiality including the clarification of facts and reasoning of the decisions together with the constitutional practice and method of interpretation, the following conclusion is deduced: the authority decision examined by the Metropolitan Court in the frames of the administrative lawsuit, by not containing the facts and justification established by the investigating authority, was incomplete to such an extent that a substantive review was not possible, therefore, excluded the possibility of an effective legal remedy. Therefore, under the current rules to apply, the Metropolitan Court should have annulled the authority decision and ordered the immigration authority to reopen the proceedings (Act on TCN, art. 88R (2); CAL, art. 90 (3) d) and 92 (1) d) cf. Article 92 (1) a)).

\section{Conclusion}

The present study aimed to draw attention to the significance of reasoning of authority decisions: it is an essential condition for verifiability of legality and to avoid arbitrariness. Authorities shall give adequate reasons for their decisions under all circumstances. To that end, it examined the issues relating to the obligation to state reasons in a decision on the expulsion of an Iranian student on grounds of public policy, public security, through the judgment of the Metropolitan Court that made a review and it tied to evaluate the legal situation caused by the breach of the obligation as a procedural legal guarantee 
in the view of the national and international legal practice. No matter what it is called or how the available legal practice is twisted, the interpretation of the constitutional requirements, supported by the relevant international and domestic case law, the duty to incorporate the opinion of the asylum authority shall be a part of the argumentation of the immigration authority and be available for legal remedy. Summing up, the case is a message for the legislator to pay more attention to the regulation of procedural guarantees for the sui generis legal institution. 


\section{References}

Balogh-Békesi N. (1997). Alapelvek a közigazgatási hatósági eljárásban. Új magyar közigazgatás, 9(4), pp. 12-17.

Blutman, L. (1997). A kiutasítás és visszaküldés az alapjogok árnyékában. Acta Universitatis Szegediensis: acta juridica et politica, 52 (2), pp. 5-27.

Boros, A. (2006). Új jogintézmények a Ket. bizonyítási rendszerében. Jogtudományi Közlöny, 61(11), pp. 419-420.

Chronowski, N. (2014). Mikor megfelelő az ügyintézés? Uniós és magyar alapjogvédelmi megfontolások. Magyar Jog, 61(3), pp. 137-145.

CoE Handbook. The Administration and You. A handbook. Principles of administrative law concerning relations between individuals and public authorities. Strasbourg, Council of Europe, 2018.

Dudás, D.V. and Kovács, A. (2018). A közigazgatási bírósági felülvizsgálat bizonyítási-mérlegelési szabályai és terjedelme a tisztességes eljáráshoz való jog tükrében. Jogtudományi Közlöny, 73(3), pp. 155-164.

GPAPC Commentary. Aszalós, D. et al (2019). Kommentár az általános közigazgatási rendtartásról szóló 2016. évi CL. törvényhez. 2019.IV.26. Hatályos Jogszabályok Gyűjteménye - Wolters Kluwer. Online database.

GRAPS Commentary. Barabás, G. et al (2017). Nagykommentár a közigazgatási hatósági eljárás és szolgáltatás általános szabályairól szóló 2004. évi CXL. törvényhez (archív). Hatályos Jogszabályok Gyưjiteménye - Wolters Kluwer. Online database.

Hajas, B. (2016). Általános közigazgatási rendtartás — Ket. kontra Ákr. Új magyar közigazgatás, 9(4), pp. 18-25.

Hepburn, J. (2012). The Duty to Give Reasons for Administrative Decisions in International Law. International \& Comparative Law Quarterly, 61 (3), pp. 641-663. At <https://ssrn.com/abstract=2405065>, accessed 10 January 2021.

Huszárné Oláh, É. (2017). A szakhatóság közreműködése. In F. Petrik, ed., Az általános közigazgatási rendtartás magyarázata. Budapest:HVGOrac, pp. 134-138.

ICCPR Comment. International covenant on civil and political rights. General Comment on Article 4 (adopted at the 1950th meeting, on 24 July 2001). CCPR/C/21/Rev.1/Add.11. At <http://docstore.ohchr.org/SelfServices/ FilesHandler .ashx?enc=6QkG1d\%2FPPRiCAqhKb7yhsjYoiCfMKoIRv2FVaVzRk MjTnjRO\%2Bfud3cPVrcM9YR0iix49nlFOsUPO40TG7R\%2Fo7TSsorhtwUUG\% 2By2PtslYr5BldM8DN9shT8B8NpbsC\%2B7bODxKR6zdESeXKjiLnNU\%2BgQ \%3D\%3D>, accessed 10 January 2021.

Immigration Law Practice. Analysis Group of the Curia, Summary Report. 2012.El.II.F.1./9.2013. At https://kuria-birosag.hu/hu/joggyak_csop/azidegenrendeszeti-joggyakorlat-elemzo-csoport-osszefoglalo-velemenye, accessed 12 January 2021.

Kálmán, J. (2018). A szakkérdés vizsgálata a magyar közigazgatási hatósági eljárásjogban. Jogtudományi Közlöny, 73 (2), pp. 104-113.

Lapsánszky, A. (2019). A hivatalbóli eljárás. In A. Patyi ed., A közigazgatási hatósági eljárásjog jogintézményei. Budapest: Dialóg Campus, pp. 395-427.

Lock T. (2019). Article 41-42 CFR. In M. Kellerbauer, M. Klamert, and J. Tomkin, eds., The EU Treaties and the Charter of Fundamental Rights. A Commentary. Oxford:Oxford University Press, pp. 2204-2208. 
Molnár, T. (2019). A külföldiek kiutasításának korlátai a Polgári és Politikai Jogok Nemzetközi Egyezségokmányának koordinátarendszerében - 50 év távlatából. In Zs. Csapó, ed., Jubileumi tanulmánykötet az 1966. évi emberi jogi egyezségokmányok elfogadásának 50. évfordulójára. Budapest:Dialóg Campus - Wolters Kluwer, p. 183-206.

Opdebeek, I. and Somer, de S. (2016). The Duty to Give Reasons in the European Legal Are: A Mechanism for Transparent and Accountable Administrative Decision-Making? A Comparison of Belgian, Dutch, French, and EU Administrative Law. Rocznik Administracji Publicznej, (2), pp. 97-148.

Patyi, A. (2012). A hatósági eljárásjogi jogviszony fogalma és tárgya: a hatósági ügy. In A. Patyi ed., Hatósági eljárásjog a közigazgatásban. BudapestPécs:Dialóg Campus. pp. 63-85.

Stelkens, U. and Andrijauskaite, A. (2017). Added Value of the Council of Europe to Administrative Law: The Development of Pan-European General Principles of Good Administration by the Council of Europe and their Impact on the Administrative Law of its Member States. Speyer: German Research Institute for Public Administration.

Tóth, J. (2015). „... a hazájukat elhagyni kényszerülők emberi jogainak és alapvető szabadságainak védelmére". Fundamentum, 19(4) pp. 61-66.

Váradi-Tornyos, B. (2018). A megújult közigazgatási eljárásról jogelméleti megközelítésben. Jog, állam, politika, 10(1), pp. 177-190.

Varga, Zs. A. (2019). Az alkotmányosság követelménye és az eljárás alapelvei. In A. Patyi and Zs. A.Varga eds., A közigazgatási eljárásjog alapjai és alapelvei. Budapest-Pécs: Dialóg Campus, pp. 161-229.

\section{International and European Union law}

Baucher v France (App. no. 53640/00) ECtHR 24 July 2007.

C-119/97. P Union française de l'express (Ufex), formerly Syndicat français de l'express international (SFEI), DHL International and Service CRIE v Commission of the European Communities and May Courier, 4 March 1999, ECLI:EU:C:1999:116.

C-16/65. Firma G. Schwarze v Einfuhr - Und Vorratsstelle Fuer Getreide und Futtermittel, Frankfurt Am Main, ECLI:EU:C:1965:117.

C417/11. P Council of the European Union v Nadiany Bamba, 15 November 2012, ECLI:EU:C:2012:718.

C-566/14. P Jean-Charles Marchiani v European Parliament, 14 June 2016, EU:C:2016:437.

EU Charter. Charter of Fundamental Rights of the European. OJ C 326, 26.10.2012. pp. 391-407.

Hirvisaari v. Finland (App. no. 37801/97) ECtHR 1 July 2003.

Suominen v Finland (App. no. 37801/97) ECtHR 1 July 2003.

T-107/15. Uganda Commercial Impex v Council, 18 September 2017, ECLI:EU:T:2017:628.

T-256/11. Ahmed Abdelaziz Ezz and Others v Council of the European Union, 27 February 2014, EU:T:2014:93.

T-425/04, T-444/04, T-450/04 and T-456/04. French Republic and Others v European Commission, Joined Cases, 21 May 2010, ECLI:EU:T:2010:216.

TFEU. Consolidated version of the Treaty on the Functioning of the European Union. OJ C 326, 26.10.2012. pp. 47-39. 


\section{Domestic law}

15 of 1989 Decree-Law on the promulgation of the convention on the status of refugees done in Geneva on 28 July 1951 and its protocol of 31 January 1967.

165/2011. (XII. 20.) Constitutional Court Decision ABH 2011. pp. 1281-1314.

30/2015. (X. 15.) Constitutional Court Decision ABH 2015. pp. 774-813.

3171/2020. (V. 21.) Constitutional Court Order, ABH 2020. pp. 898-900.

5/2019. (III. 11.) Constitutional Court Decision ABH 2019. pp. 412-417.

7/2013. (III.1.) Constitutional Court Decision, ABH 2013. pp. 382-391.

3487/2020. (XII. 22.) Constitutional Court Order, ABH 2020. pp. 2737- 2739.

2.Kf. 28.405/2004/2. Metropolitan Regional Court Judgment.

2.Kf.27.236/2008/6. Metropolitan Court of Appeals.

2.Kf.27.237/2008/7. Metropolitan Court of Appeals.

20.K.33.146/2011/4. judicial decisions.

4.Kf.27.031/2005/9. Metropolitan Court of Appeals.

4.Kf.27.369/2006/7. Metropolitan Court of Appeals.

42.K.32.031/2019/8. Metropolitan Administrative and Labour Court.

204/2015. (VII. 23.) Government Decree on the modification of Government Decree 375/2010. (XII. 31.) on aid for public employment and the legal

harmonization of certain migration, asylum, and other government decrees.

Act CIX of 2006 on amendments to the law related to the formation of governmental organization.

Act CLV of 2009 on the protection of classified information.

Act CLXV of 2013 on complaints and public interest notifications.

Act CXL of 2004 on the general rules of administrative proceedings and services.

Act CXLIII of 2017 on amendments to the law related to the migration.

Act on TCN. Act II of 2007 on the Admission and Right of Residence of Third-

Country Nationals.

BH2011.179. Judicial Decision.

BH2016.316. Judgment.

BH2019.91. Judgment.

CAL. Act I of 2017 on the code of administrative litigation.

Constitution. Act XX of 1949 on the constitution of the Hungarian Republic [no longer in force]

Constitutional complaint - Constitutional complaint against Metropolitan Court Judgment 15.K.701.176/2020/4 filed as case IV/01013/2020. available in the Hungarian language on the website of the Constitutional Court. At <http:// public.mkab.hu/dev/dontesek.nsf/0/DA7553273FBDB2AFC1258589005BEB5 9?OpenDocument> accessed 10 January 2021.

EBH2017. K.8. Judgment in principle.

Executive Decree. Government Decree 114/2007. (V. 24.) on the execution of Act II of 2007 on Act on the Admission and Right of Residence of ThirdCountry Nationals.

FL. The Fundamental Law of Hungary (25 April 2011) [hereinafter: FL] See English translation on the website of the Constitutional Court. At < https://hunconcourt.hu/uploads/sites/3/2020/11/ 
thefundamentallawofhungary_20191213_fin.pdf> accessed 10 January 2021.

FT 20.K.32.700/2011/10. judicial decisions.

GPAPC. Act CL of 2016 on general public administration procedures. English translation. At <https://njt.hu/translated/doc/J2016T0150P_20200722_FIN. $p d f>$ accessed 10 January 2021.

GRAPS. Act CXL of 2004 on the General Rules of Administrative Proceedings and Services [no longer in force]

Judgment. 15.K.701.176/2020. Metropolitan Court Judgment.

KF.II.25074/1994/4. Supreme Court Judgment.

KF.IV.37.291/2004/2. Supreme Court Judgment.

KFv.I. 35.534/1999. Supreme Court Judgment.

Kfv.l.35.066/2016/7. Curia Judgment.

Kfv.III.27.519/1997/6. Supreme Court Judgment.

Kfv.III.35.425/2015/7. Curia judgment.

Kfv.III.37.191/2006/7. Supreme Court Judgment.

Kfv.III.37.315/2012/4. Curia judgment.

KFv.III.37.587/2011/7. Curia Decision.

Kfv.V.35.538/2009/5. Supreme Court Judgment.

Kfv.X.37.055/2001/5. Supreme Court.

Kfv.X.37.055/2001/5. Supreme Court.

KGD2012.196. Administrative-Economic Decision.

KGD2013.47. Administrative-Economic Decision.

KGD2015.91. Administrative-Economic Decision.

KGD2016.27. Administrative-Economic Decision.

KGD2019.105 Administrative-Economic Decision. 